\title{
Vocational Education, Per Capita Income, and Employment in the US
}

\author{
Eric Im, posthumous \\ Gene Johnson \\ College of Business and Economics, University of Hawaii-Hilo, USA
}

Tam Vu (Corresponding author)

College of Business and Economics, University of Hawaii-Hilo

200 West Kawili Street, Hilo, HI 96720, USA

Tel: 808-932-7485_Email: tamv@ hawaii.edu

Received: October 19, 2017 Accepted: November 3, 2017

doi:10.5296/ber.v7i2.12011ＵRL: https://doi.org/10.5296/ber.v7i2.12011

\begin{abstract}
This paper examines the effects of vocational education on per capita income and employment in the U.S. A panel dataset on the number of graduates from community colleges as a proxy for vocational education for fifty states and Washington D.C. during 2002-2010 is used. The method of three stage least squares was employed. The results show that vocational education appears to affect changes in per capita income and employment positively. Nest, we compare and contrast vocational education with university education by using data on the number of four-year college graduates. The results show that the vocational education increases per capita income and employment more than university education in the short run but less than the latter in the long run.
\end{abstract}

Keywords: Community colleges, Employment, Per capita income, Three stage least squares

\section{Introduction}

The recent economic recession has caused high unemployment in many sectors of the US economy and the resulting deterioration of household incomes. In the meantime, facing constraints in financial means, many firms are looking for job candidates with practical skills instead of deep knowledge in liberal art education. In addition, the federal government also seems to shift its attention and plans to give more favorable consideration in its distribution 
of financial aids to community colleges. For example, President Obama recently announced a plan to finance free education to any student who decides to attend a community college. This raises the question of whether or not four-year college education is still the staple of investment in human capital for most households in the US.

Reviewing existing literature turns up not any paper investigating these two levels of education in relation to per capita income using panel data at the state level. The question is: does the US really need so many university graduates to improve its living standard?

Section two of the paper provides a review of the existing literature. Section three introduces a regression model and discusses data issues. Section four analyzes the results and offers a non-regression calculation as an intuitive explanation of the regression results. Section five concludes.

\section{Existing Literature}

There are several papers on education and per capita income. Lucas (1998), Romer (1990), and Aghion and Howitt (1992) revised the original Slow (1957) paper into a "new growth" model. With research and development (R\&D) as human capital. Kremer (1993) then revised this model for education as human capital in closed economy and by Barro et al. (1995) for an open economy. Baumol (1990) found that the effect of education on per capita income depends on some specific characteristics such as political and economic stability. Barro et al. (1995) examines an open economy and found that education increases per capita income and employment only if a nation can finance its education with its own savings instead of borrowing from foreigners.

Despite the fact that many "new growth" models are developed for productivity defined as GDP per worker, empirical studies have focused on GDP per capita instead of productivity. Barro (1991) uses cross sectional data for 98 countries, single equation estimation, and ratios of primary and secondary enrollments to population (henceforth call the enrollment ratios) and finds that education has a positive effect on GDP per capita. Mankiw et al. (1992), Levine and Renelt (1992), Levine and Zervos (1993), Barro and Lee (1993), and Kremer (1993), in their slightly modified models and single equation estimations, all confirm Barro's results.

There are several papers examine the effect of education on growth of productivity instead of per capita income in addition to Bils and Klenow (2000) and Kumar (2003). Knight et al. (1993) extend the paper by Mankiw et al. (1992) by using panel data and examine the effect of education on output per worker. Performing single equation estimations, they find that this effect is positive. Benhabib and Spiegel (1994) perform single equation estimations and find that education affects GDP per capita positively.

Klenow and Rodrigues (1997) and Hall and Jones (1999) tackle the question of to what extent the differences in output per worker among countries are due to the differences in schooling. They compare the five richest countries to the five poorest and find that the ratio of the average output per worker in the rich group to the poor one is roughly 30:1. Performing single equation estimations, they find that less than a quarter of this gap is due to differences 
in schooling. Islam (1995) also shows that higher growth in labor productivity leads to higher growth in per capita income, that is, these two variables are highly correlated to each other.

Behrman and Knowles (1999) find that children in higher income families receive more education than those in lower income families. A careful observation of the historical data from the United Nation and the World Bank also reveals that countries with higher productivity levels tend to have higher rates of school enrollments. This particular paper and the data also support the development theory argued in Thirwall (2006) and Lynn (2003).

Bils and Klenow (2000) used OLS on two single equation estimations for cross sectional data of 81 to 93 countries. They found that education only has a very weak effect on GDP per capita, but this GDP increase in turn has a positive effect on school enrollments. Hojo (2003) used the country-specific residual from the regression by Caselli et al. (1996) as a proxy for productivity. Employing the GMM procedure introduced by Arellano and Bond (1991) on a single equation for cross sectional data of 90 countries, he found that education has positive effect on productivity. Since higher productivity is related to a higher GDP per capita as shown in Islam (1995), Hojo's results imply that education can indirectly affect GDP per capita through productivity improvement at national level.

However, all aforementioned papers use single equation estimations, so their coefficient estimates will be biased if a two-way causality between education and GDP per capita exists. Kumar (2003) was the first author to develop a model for the feedback effect. He used the two stage least squares (2SLS) approach for a system of equations and cross sectional data with 68 to 91 observations. In accordance with Hojo (2003) but in contrast to Bils and Klenow (2000) he found that education clearly increases productivity growth, but this growth in turn has a negative effect on enrollments instead of a positive one as in Bils and Klenow. There is a problem with his 2SLQ estimations because they are only asymptotically consistent. This calls for large sample sizes, but Kumar's sample has only 68 to 91 observation data sets at national level, so the results might be biased.

$\mathrm{Vu}$ at al. (2012) addressed Kumar's problem by using larger panel data set and a more advanced econometric method of three stage least squares (3SLS). They found that the two way causality are both positive. They also find that that vocational education increases labor productivity more than university education. On the reverse causality, they find that the effect of productivity growth on vocational-school enrollments is higher than on university enrollments. $\mathrm{Vu}$ and $\mathrm{Im}$ (2011) repeated the same exercise for the case of Vietnam as a specific developing country. They found that vocational education helped regional development in Vietnam more than university education. On the reverse causality, they found that the effect of regional development on university enrollments is higher than on vocational-school enrollments. This paper looks for answers to the US as one of the most developed countries using the same large panel data set and the advanced method of three stage least squares (3SLS).

\section{Model and Data}

We use an augmented Cobb-Douglas production function similar to a "new growth model" 
and provide a second equation to account for the possible two-way causality:

$$
\begin{gathered}
y_{i t}=B+\lambda k_{i t}+\theta e_{i t}+\sum_{j=1}^{n} \gamma_{j} a_{j t}+\sum_{l=1}^{m} \phi_{l} A_{l t}, \\
e_{i t}=D+\alpha y_{i t}+\sum_{p=1}^{r} \eta_{j} c_{j t}
\end{gathered}
$$

where $y$ is real GDP per capita or employment, B and $D$ are the shift parameters, $k$ is capital per worker, and $e$ is education ratio, which can be measured by school enrollments per capita, numbers of graduates per capita,. a is a vector of auxiliary variables in growth rates such as physical capital, infrastructure, etc. $A$ is another vector of auxiliary variables in levels such as initial real GDP per capita or initial level of per capita income, etc. The subscript $i$ is the stat index, $t$ time index, and $c$ is a vector of control variables such as public expenditures on education, private total expenditures, etc.

Data on the numbers of graduates from community colleges and four-year colleges., as well as school enrollments, for fifty states and Washington D.C. during the school years 2002-2010 are from the National Center for Education Statistics (NCES) website. Data for the school years 2004-2006 are from Table 3a01, "Number of degrees conferred in Title IV institutions, by award level, gender, and state." Data for the school years 2006-2008 are from Table 335, "Degrees conferred by degree-granting institutions, by level of degree and state or jurisdiction." Data for the school year 2008-2009 are from Table 332, "Degrees conferred by degree-granting institutions, by control, level of degree, and state or jurisdiction." Data for 2009-2010 are from the "State Education Data Profiles," also published by the NCES.

Data on the gross state products, employment, federal government expenditures on education, investment on physical capital, expenditures on medical facilities (as a proxy for health care), domestic trade, expenditures on transportation and warehousing (as a proxy for infrastructure), state and local government expenditures, household expenditures on education, information technology, and expenditures on social assistances for fifty states and Washington D.C. during 2004-2012 are from the Bureau of Economic Analysis (BEA). All measures are in current dollars and therefore data on the price indices for GDP (implicit GDP deflators) from the BEA are used to convert them to real values. There are missing observations in the remaining data, so we have an unbalanced panel.

Table 1 provides the descriptive statistics of the data on these two levels of education. The table reveals that the number of bachelor degree holders is more than twice that of associate degree holders. 
Table 1. Number of Community College versus Four-Year College Graduates in the U.S.

\begin{tabular}{|l|l|l|l|l|l|l|}
\hline Period & $2002-2004$ & & $2005-2007$ & & $2008-2010$ & \\
\hline Region & Associate & Bachelor & Associate & Bachelor & Associate & Bachelor \\
\hline United States & 1894890 & 4040253 & 2160124 & 4487575 & 2524708 & 4649679 \\
\hline New England & 81084 & 262904 & 81125 & 285170 & 89356 & 294575 \\
\hline Mideast & 303661 & 734036 & 335245 & 805483 & 375972 & 827693 \\
\hline Great Lakes & 277937 & 685294 & 331640 & 742903 & 367297 & 760277 \\
\hline Plains & 153839 & 344630 & 180139 & 376616 & 198238 & 391666 \\
\hline Southeast & 444613 & 887434 & 513275 & 988830 & 596150 & 1032946 \\
\hline Southwest & 181629 & 390257 & 239885 & 458863 & 332486 & 484929 \\
\hline Rocky Mountain & 79297 & 167768 & 83190 & 190086 & 105757 & 195398 \\
\hline Far West & 372830 & 567930 & 395625 & 635936 & 427951 & 654991 \\
\hline
\end{tabular}

Source: National Center for Education Statistics, https://nces.ed.gov/

Table 2 shows the distribution of average earning by education attainment in the U.S. It appears that four-year college graduates earn substantially more than the community-college graduates. However, several authors have found that vocational education increases productivity more than university education does. Since increase in productivity often leads to increase in per capita income, does the results imply that vocational education can increase per capita income more than university education does? This paper attempts to answer these questions.

Table 2. Mean Per Capita Income by Education in the U.S. (\$ US)

\begin{tabular}{|l|l|l|l|l|l|l|}
\hline Education Attainment & $2002-4$ & & $2005-07$ & & $2008-10$ & \\
\hline Level of Highest Degree & Mean & STDEV & Mean & STDEV & Mean & STDEV \\
\hline Not a high school graduate & 18,784 & 47 & 19,986 & 854 & 20,916 & 628 \\
\hline High school graduate & 27,330 & 562 & 29,721 & 1,236 & 31,065 & 380 \\
\hline Some college, no degree & 29,451 & 323 & 31,296 & 1,062 & 32,620 & 361 \\
\hline Associate's & 34,960 & 910 & 37,915 & 1,847 & 39,674 & 146 \\
\hline Bachelor's & 51,008 & 333 & 54,344 & 2,634 & 57,486 & 1,009 \\
\hline Master's & 62,184 & 1,599 & 68,399 & 1,762 & 71,593 & 1,887 \\
\hline Professional & 109,811 & 7,401 & 116,715 & 2,201 & 124,600 & 3,432 \\
\hline Doctorate & 87,960 & 2,077 & 96,604 & 6,357 & 99,439 & 3,751 \\
\hline
\end{tabular}

Note: "mean" denotes average income per year, and "STDEV" is the standard deviation.

Source: U.S. Census Bureau, http://www.census.gov/hhes/socdemo/education/

\section{Results and Analysis}

We start using all available variables to avoid omitted variables and performing the Variance Inflation Factors (VIF) tests on the possible multicollinearity as discussed in Kennedy (2006). The first model is for per capita income as dependent variable, the second one is for employment as dependent variable, After several rounds of the VIF tests to eliminate 
variables with VIF > 10, we end up with four variables for Equation (1) and three variables for Equation (2) in the system of two equations.

Next, we perform the AIC procedures and find that model without lag value is the best with the smallest ACI value. In the following step, we carry out the Granger Causality tests to investigate the possible two-way causality. The results show that there is feedback effect where per capita income affects both school enrollments and number of graduates. This justifies our use of the three stage least squares method.

We then perform the endogeneity Hauman test, called the second variant of the Hausman test in Kennedy (2008), and find that the per capita income has an endogenous problem: the p-value of the residual collected is 0.018 , so IV estimations are needed. Different from cross sectional estimations, in which finding an instrumental variable (IV) is very difficult, the panel-data estimations enable the use of lagged variables as IVs. In the first stage, we regress the endogenous variable on all exogenous variables using the Blundell-Bond System GMM procedure as described in Bond (2002) to control for the lagged dependent variable problem. In the second stage, the predicted value of this regression is used as IV in the second regression.

The original Hausman tests performed for model selection indicates that a fixed effect (FE) model is more suitable than random effect (RE) one for either model with per capita income or employment ratio: p-values are less than 0.05 for both models, implying that the null hypotheses of random effect estimations are rejected. Thus, all estimations are carried out using fixed effect approach of least squares dummy variables (LSDV) with both country dummies and time dummies added as discussed in Greene (2012).

The Ramsey RESET test shows that the models do not have any important omitted variable with the $\mathrm{p}$-value $=0.536$. However, the White tests reveal that there are heteroskedasticity problems on both models: p-values are consistently less than 0.05 . Therefore, the subsequent regressions are performed using the Stata robust commands to obtain corrected standard errors.

Table 3 reports the results for model with per capita income as dependent variable. Hojo (2003) found that education increases productivity and uses the results in Islam (1995) to argue that higher productivity will lead to higher per capita income. Based on this, he argued that vocational education might increase per capita income more than university education. Our results support his claim: Panel 3a) reports the effect of vocational education on per capita income growth and reveals that one percent increase in community college graduates raises per capita income by roughly three percent, and the coefficient estimate is statistically significant. As discussed in Greene (2012) the value R-squared does not convey any meaningful interpretation. Hence, we report the Root Mean Squared Error (RMSE) values in Table 3 and 4. The smaller the RMSE, the better fit the model. The signs of all other variables are as expected, including the sign of the initial per capita income, which confirms the convergent theory in economics: the lower the initial income, the faster the growth rate of per capita income. 


\section{Ml Macrothink}

Table 3. Results for the Effect of Vocational Education on Per Capita Income

\begin{tabular}{|lllll|}
\hline \multicolumn{5}{|l|}{ Panel (3a) Dependent variable: Growth of Per Capita Income } \\
\hline Variable & Coefficient & p-value & [95\% Conf. Interval] \\
\hline Com-college Graduates & $.0323^{* *}$ & .029 & .0099 & .0383 \\
\hline Infrastructure & $.0048^{* *}$ & .016 & .0012 & .0047 \\
\hline Physical Capital & $.1326^{* *}$ & .032 & .0341 & .1967 \\
\hline Initial GDP per Capita & $-.0781^{* *}$ & .027 & -.0024 & .0289 \\
\hline Panel (3b) Dependent Variable: Growth of Graduates per Capita & \\
\hline Financial Aids & $.0059^{* *}$ & .015 & .0012 & .0065 \\
\hline Health Care & $.0025^{*}$ & .058 & .0008 & .0145 \\
\hline GDP per Capita & $-.0176^{* *}$ & .024 & -.0006 & .0542 \\
\hline Number of observations & $=408$ & & \\
\hline F( 59, 348$)$ & $=1024$ & & \\
\hline Prob > F & $=.0006$ & & \\
\hline RMSE & $=.0756$ & & \\
\hline
\end{tabular}

Note: $*$ and $* *$ denotes five percent and one percent statistically significant, respectively

“Com-college" denotes community college.

Panel (3b) reports the reversed effect of per capita income growth on vocational education and shows that there is a negative and significant effect. The results confirm those in Kurma (2003) and imply that the opportunity costs of going back to colleges increase when income rises, causing the potential college students to think twice before quitting their jobs to attend colleges. The signs of all other variables are as expected.

We then repeat the same exercise with the model for employment ratio and display the results in Table 4. The results again show that vocational education appears to affect employment ratio positively and significantly. The signs of all other variables are again as expected. We also estimate the above models using data on enrollments. The results, which are similar to those in Tables 3 and 4 , are available upon requests. 


\section{Macrothink}

Business and Economic Research

Table 4. Estimation Results for the Effect of Vocational Education on Employment

Panel (3a) Dependent variable: Growth of Employment per Capita

\begin{tabular}{|lllll|}
\hline Variable & Coefficient & p-value & \multicolumn{2}{c|}{ [95\% Conf. Interval] } \\
\hline Com-college Graduates & $.0258^{* *}$ & .023 & .0043 & .0365 \\
\hline Infrastructure & $0036^{* *}$ & .029 & .0011 & .0052 \\
\hline Physical Capital & $.0778^{* *}$ & .028 & .0132 & .0923 \\
\hline Initial Employment & $.0056^{*}$ & .087 & .0018 & .0076 \\
\hline Panel (3b) Dependent Variable: Growth of Graduates per Capita & \\
\hline Financial Aids & $.0052^{* *}$ & .018 & .0013 & .0067 \\
\hline Health Care & $.0027^{*}$ & .076 & .0009 & .0148 \\
\hline GDP per Capita & $-.0152^{* *}$ & .029 & -.0009 & .0674 \\
\hline Number of observations & $=408$ & & \\
\hline F( 59, 348$)$ & $=1097$ & & \\
\hline Prob $>$ F & $=.0009$ & & \\
\hline RMSE & $=.0948$ & & \\
\hline
\end{tabular}

Note: $*$ and $* *$ denotes five percent and one percent statistically significant, respectively

To compare and contrast the effect of vocational college education to university education, we add data on the number of graduates from four-year colleges in fifty states and Washington D.C. to the original model. Two variables are added: one is current university graduates (UGRAD) and the other is a five year lagged variable (UGRADLAG. The original Hausman tests performed for model selection again indicates that a fixed effect (FE) model is more suitable than random effect (RE) one for either model with per capita income or employment ratio: p-values are less than 0.05 for both models, implying that the null hypotheses of random effect estimations are rejected. Thus, all estimations are carried out using fixed effect approach of least squares dummy variables (LSDV) with both country dummies and time dummies added. Table 5 reports the results. 
Table 5. Comparative Effects: Vocational versus University Education

Panel (3a) Dependent variable: Growth of Per Capita Income

\begin{tabular}{|lllll|}
\hline Variable & Coefficient & $\mathrm{p}$-value & \multicolumn{2}{c|}{ [95\% Conf. Interval] } \\
\hline Com-college Graduates & $.0313^{* *}$ & .023 & .0078 & .0354 \\
\hline UGRAD & $.0203^{* *}$ & .032 & .0056 & .0312 \\
\hline UGRADLAG & $.0412^{* *}$ & .019 & .0087 & .0645 \\
\hline Infrastructure & $.0045^{* *}$ & .019 & .0011 & .0043 \\
\hline Physical Capital & $.1312^{*} *$ & .039 & .0332 & .1765 \\
\hline Initial GDP per Capita & $-.0701^{*} *$ & .021 & -.0029 & .0312 \\
\hline Panel (3b) Dependent Variable: Growth of Graduates per Capita & \\
\hline Financial Aids & $.0052^{*} *$ & .019 & .0011 & .0059 \\
\hline Health Care & $.0021 *$ & .084 & .0009 & .0132 \\
\hline GDP per Capita & $-.0143 * *$ & .027 & -.0007 & .0498 \\
\hline Number of observations & $=408$ & & & \\
\hline F( 59, 348$)$ & $=1143$ & & & \\
\hline Prob > F & $=.0003$ & & \\
\hline RMSE & $=.0793$ & & \\
\hline
\end{tabular}

Note: $*$ and $* *$ denotes five percent and one percent statistically significant, respectively

“Com-college" denotes community college.

"University Graduate" denotes four-year college graduates.

From this table, the effect of vocational education on per capita growth is fifty present greater than that of the university education in the short run and significantly so. However, the effect of vocational education on per capita growth is 25 present smaller than that of the university education in the long run. Hence, only the short run results support the ones in $\mathrm{Vu}$ at al (2012), who used data for all countries worldwide.

\section{Conclusion}

In this research, we examine the effect of vocational education on per capita income and employment in the U.S. The method of three stage least squares was employed. A panel dataset on the number of graduates from community colleges as a proxy for vocational education for fifty states and Washington D.C. during 2002-2010 is used. The results show that vocational education appears to affect changes in per capita income and employment positively.

Nest, we compare and contrast vocational education with university education by using data on the number of four-year college graduates. The results show all positive and significant coefficient estimates. This implies that the education variable, regardless of which level is used in an empirical study, will yield a similar effect on economic growth. It further implies that the use of secondary school enrollments as a proxy for education by most authors in the 
existing literature is only an arbitrary choice. The results also reveal that the effect of university education on per capita income is lower than that of community-college education in the short run. This supports the results reported in Vu et al. (2012). The long run effect is in reverse, implying that is a person has a long life to enjoy after graduation, then university education becomes more beneficial economically

The data is not comprehensive, so the results might have small biases . We try to overcome this problem by providing results on interval estimates in addition to exact magnitude of the point estimates. The same exercise can be repeated and new interpretation can be drawn when data that are more comprehensive become available.

\section{References}

Aghion, P., \& Howitt, P. (1992). A Model of Growth through Creative Destruction. Econometrica, 60, 323-351. https://doi.org/10.2307/2951599

Akaike, H. (1973). Information Theory and Extension of the Maximum Likelihood Principle. In $2^{\text {nd }}$ International Symposium on Information theory, Budapest, Hungary: Akademiai Kiado, 267-282.

American Association of Community Colleges. (2014). Fast facts. Retrieved April 19. Retrieved from http://www.aacc.nche.edu/AboutCC/Documents/Facts14_Data_R2.pdf.

Arellano, M., \& Bover. O. (1995) Another look at the instrumental variables estimation of Error components models. Journal of Econometrics, 68, 29-51.

https://doi.org/10.1016/0304-4076(94)01642-D

Arellano, M., and Bond, S. (1991). Some Test of Specification for Panel Data: Monte Carlo Evidence and an Application for Employment Equations. The Review of Economic Studies, 58(2), 277-297. https://doi.org/10.2307/2297968

Barro, R. J. (1991). Economic Growth in a Cross-Section of Countries. Quarterly Journal of Economics, 106(May), 407-443. https://doi.org/10.2307/2937943

Barro, R. J., \& Lee, W. (1993). Losers and Winners in Economic Growth. Proceedings of the World Bank Conference on Economic growth Washington, D.C. World Bank, 1994, 54-89. https://doi.org/10.3386/w4341

Barro, R. J., \& Sala-i-Martin, X. (2004). Economic Growth. Cambridge, MA: MIT Press.

Barro, R. J., Mankiw, G., \& Sala-i-Martin, X. (1995). Capital Mobility in Neoclassical Models of Growth. American Economic Review, 85, 103-115.

Baumol, W. (1990). Entrepreneurship: Productive, Unproductive, and Destructive. Journal of Political Economy, 98, 893-921. https://doi.org/10.1086/261712

Behrman, J., \& Knowles, J. (1999). Household Income and Child Schooling in Vietnam. World Bank Economic Review, 13(2), 211-256. https://doi.org/10.1093/wber/13.2.211

Belfield, C. R., \& Bailey, T. (2011). The benefits of attending community college: A review 
of the evidence. Community College Review, 39, 46-68.

https://doi.org/10.1177/0091552110395575

Belfield, C., \& Jenkins, D. (2014). Community College Economics for Policymakers: The One Big Fact and the One Big Myth. Community College Research Center Working Paper 67. Community College Research Center, Columbia University.

Benhabib, J., \& Spiegel, M. M. (1994). The Role of Human Capital in Economic Development.Journal of Monetary Economics, 34, 143-173.

https://doi.org/10.1016/0304-3932(94)90047-7

Bils, M., \& Klenow, P. (2000). Does Schooling Cause Growth? American Economic Review, 90(5), 1160-1183. https://doi.org/10.1257/aer.90.5.1160

Bond, S. (2002). Dynamic panel data models: A guide to micro data methods and practice. CEMMAP working paper CWP09/, 02. https://doi.org/10.1007/s10258-002-0009-9

Carnevale, A. P., Rose, S. J., \& Cheah, B. (2013). The college payoff: Education, occupations, lifetime earnings. The Georgetown University Center on Education and the Workforce.

Carnevale, A. P., Smith, N., \& Strohl, J. (2010). Help wanted: Projections of jobs and education requirements through 2018. The Georgetown University Center on Education and the Workforce.

Dadgar, M., \& Weiss, M. (2012). Labor Market Returns to Sub-Baccalaureate Credentials: How Much Does a Community College Degree or Certificate Pay? Community College Research Center Working Paper 45. Community College Research Center, Columbia University.

Green W. H. (2012). Econometric Analysis, eighth edition. New York, NY: Pearson.

Islam, N. (1995). Growth empirics: a panel data approach. Quarterly Journal of Economics, 110, 1127-1170. https://doi.org/10.2307/2946651

Jepsen, C., Troske, K., \& Coomes, P. (2014). The labor-market returns to community college degrees, diplomas, and certificates. Journal of Labor Economics, 32(1), 95-121. https://doi.org/10.1086/671809

Kane, T. J., \& Rouse, C. (1995). Labor-market returns to two-and four-year college. American Economic Review, 85(3), 600-614.

Kasper, H. T. (2003). The changing role of community college. Occupational Outlook Quarterly, 46(4), 14-21.

Kennedy, P. (2006). A Guide to Econometrics, 6th edition. Cambridge, MA: MIT Press.

Krugman, P. R. (1997). The age of diminished expectations: US economic policy in the 1990s. Cambridge, MA: MIT press.

Kumar, K. B. (2003). Education and Technology Adoption in a Small Open Economy: Theory and Evidence. Macroeconomic Dynamics, 7(4), 586-617. 
https://doi.org/10.1017/S1365100503020170

Kurre, J. A., \& Andrews, P. (2013). What Determines Labor Productivity Differences for Manufacturing Industries Across US Metro Areas? Paper presented at The 52nd Annual Meeting of the Southern Regional Science Association, Arlington, VA.

Monk-Turner, E. (1995). Economic returns to community and four-year college education. The Journal of Socio-Economics, 23(4), 441-447.

https://doi.org/10.1016/1053-5357(94)90013-2

Mullin, C. M. (2011). A Sound Investment: The Community College Dividend. AACC Policy Brief 2011-01PBL. American Association of Community Colleges.

Romer, D. (2006). Advanced Macroeconomics. Boston, MA: MacGraw-Hill.

Spetz, J. (2002). The value of education in a licensed profession: the choice of associate or baccalaureate degrees in nursing. Economics of Education Review, 21(1), 73-85.

https://doi.org/10.1016/S0272-7757(00)00047-9

Spetz, J., \& T. Bates (2013). Is a Baccalaureate in Nursing Worth It? The Return to Education, 2000-2008. Health Services Research, 48(6), 1859-1878.

https://doi.org/10.1111/1475-6773.12104

Vedder, R., Denhart, C., \& Robe, J. (2013). Why Are Recent College Graduates Underemployed? University Enrollments and Labor-Market Realities. Center for College Affordability and Productivity.

Vu, T. B., Hammes, D. L., \& Im, E. (2012). Vocational or University Education? A New Look at Their Effects on Economic Growth. Economics Letters, 117(2), 426-428.

https://doi.org/10.1016/j.econlet.2012.06.027

\section{Copyright Disclaimer}

Copyright for this article is retained by the author(s), with first publication rights granted to the journal.

This is an open-access article distributed under the terms and conditions of the Creative Commons Attribution license (http://creativecommons.org/licenses/by/3.0/). 